\title{
CIDADE SITIADA, O MEDO COMO INTRIGA ${ }^{1}$
}

\author{
Ana Luiza Carvalho da Rocha
}

Cornelia Eckert

\section{Prólogo}

Imagens da cidade amanhecendo (céu sem nuvens). Falas das velhas senhoras (plano fechado no rosto das velhinhas, ao fundo imagens da cidade de Porto Alegre, em velocidade acelerada, em evocação a passagem do tempo)

D. Orientina: É a gente ver aquilo que não gostaria de ver, passar pelo que não quer.... A minha infância. A gente naquela época era muita segura. A gente não saía, não tinha assim liberdade, né. Era em casa. Ali a gente, eu me criei ali, estudei em Cruz Alta...

Vó Santa: Faço oração com a Bíblia na mão, eu caminho com ela e aonde eu vou eu levo, eu não deixo... é a minha espada que eu tenho comigo é a minha espada, o poder que eu tenho comigo é a palavra do Senhor, a biblia aberta e a boca do Senhor falando conosco, eu confio nisso e confio em Deus.

\section{Introdução ou "préfiguração"}

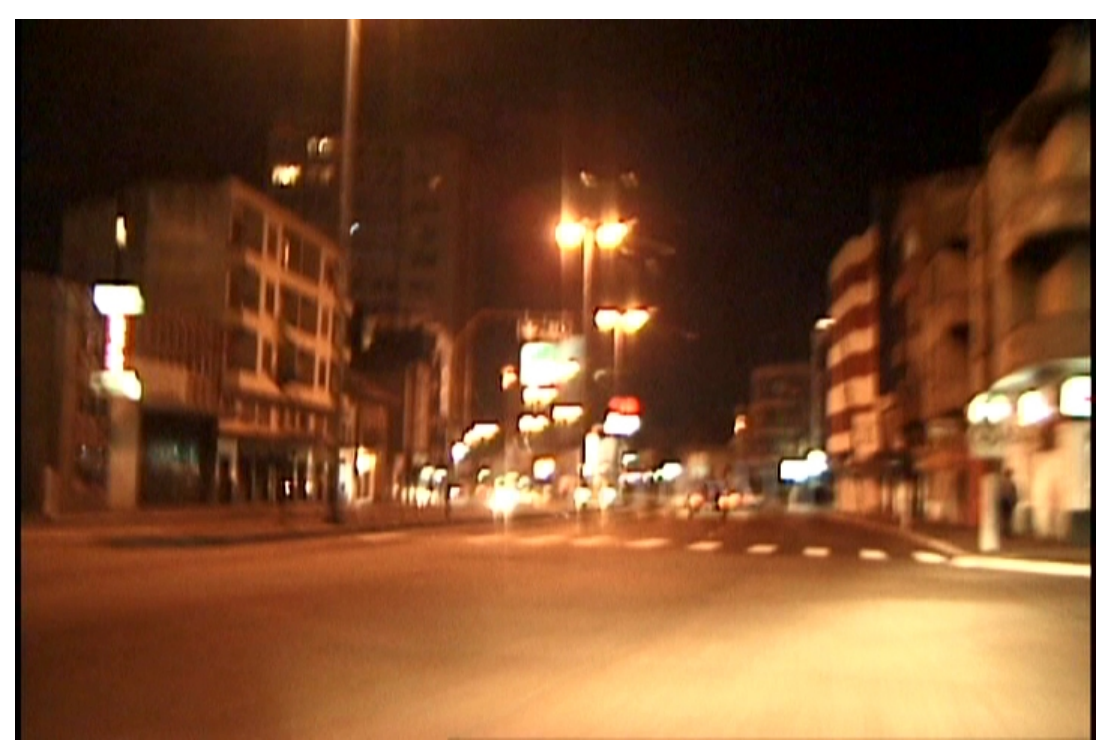

Cidade Sitiada. NTSC / 24min / MiniDV / 2001. Direção: Ana Luiza Carvalho da Rocha e Cornelia Eckert. Câmera Rafael Devos. Produção Equipe Biev

Através dessas vozes inicia-se o documentário Cidade sitiada, seus fantasmas e seus

\footnotetext{
${ }^{1}$ Agradecemos as organizadoras do Seminário "Medo: Perspectivas Urbanas" (PPGAS, UnB) pelo convite em publicar nesta coletânea, em especial a colega Cristina Patriota de Moura pela oportunidade de exibir o documentário "Cidade Sitiada" por ocasião do evento.
} 
$\underline{\text { medo }^{2}}$ que realizamos em 2001 sobre a cultura do medo a partir da trajetória de vida de quatro habitantes em Porto Alegre. Trata-se de documentário etnográfico que retrata as feições da crise e do medo no teatro da vida urbana contemporânea dessa cidade de 1,42 milhões de pessoas (capital do estado do Rio Grandes do Sul), a partir dos itinerários de seus diferentes personagens, ressaltando-se o conteúdo trágico que encerram as inflexões por eles apontadas entre tempo passado e tempo presente na genealogia da controvérsia de suas ambiências "acolhedoras" ou "ameaçadoras".

Sendo concebido na trilha de conceitos antropológicos sobre as feições das crises nas grandes cidades do país, o documentário etnográfico ressalta $\mathrm{o}$ tratamento diferencial das figuras do imaginário do medo no contexto urbano. Seguem-se os rastros da memória de habitantes em seus cotidianos a partir de seus relatos biográficos segundo recortes distintos de classe, etnia, geração e de gênero. Nesse sentido, as formas da crise pela insegurança, pela vulnerabilidade, pela vitimização e a estética do medo pela proteção patrimonial vão sendo configurados a partir dos itinerários de seus diferentes personagens ressaltando-se o conteúdo trágico que encerram as inflexões por eles apontadas entre experiências passadas e o tempo vivido no presente.

A idéia inicial previa remontar uma genealogia da controvérsia das ambiências "acolhedoras" ou "ameaçadoras" em Porto Alegre. No entanto, através dos relatos e das entrevistas com os informantes, isso não foi possível. Optou-se, assim, na construção do roteiro final de edição para o desenvolvimento do argumento original, na escolha de dois personagens centrais cujas trajetórias sociais e histórias de vida na cidade de Porto Alegre permitem ao espectador se confrontar com a complexidade das representações de medo e de crise no mundo urbano contemporâneo. Escolhemos, então, como protagonistas da história a ser narrada pelo documentário os relatos de Augusto (um pai de família de camadas médias, branco, engenheiro, morador de um condomínio horizontal), e Marlene (uma mãe de família, empregada doméstica, negra, oriunda das classes populares), ambos habitantes de uma vila de periferia nos arredores de Porto Alegre.

\footnotetext{
${ }^{2}$ Produção audiovisual (com captação em formato Mini-DV e finalização em formato DVCAM), de cunho documental, visando o debate atual sobre a crise nos grandes centros brasileiros (crescimento desordenado, aumento da violência e da criminalidade, miséria e desemprego, intolerância às diferenças sociais e étnicas, entre outras), o objetivo central do documentário é retratar a experiências dos habitantes de uma grande cidade brasileira que vivenciam estas experiências caóticas em seu cotidiano.
} 
No sentido de marcar a própria passagem do tempo que se tornou uma marca dos depoimentos dos dois personagens centrais, escolhemos duas personagens nas figuras de duas vozes de velhas senhoras (D. Orientina e D. Etelvina, "vó Santa“), através das quais o espectador poderia acompanhar a trama que estava sendo narrada, a partir de seus comentários sobre a própria cidade e suas transformações no tempo. A intenção era que essas narradoras ocupassem o lugar do "coro" nas tragédias gregas, comentando, a distância, as ações, os sentimentos e os pensamentos dos personagens em suas dramáticas e em suas interpretações no fluxo do tempo vivido.

O uso de imagens de acervo para construir a atmosfera de suas trajetórias concentrou-se no próprio acervo pessoal dos informantes, com algumas inserções de imagens aéreas da cidade de Porto Alegre do acervo do Banco de Imagens e Efeitos Visuais (BIEV), sendo que todas as imagens utilizadas foram produzidas especialmente para realização deste documentário. A equipe de realização era reduzida com o intuito de garantir a qualidade da posição e presença dessa equipe na vida cotidiana dos informantes, no bairro onde moram, bem como sua inserção discreta e processual embora, muitas vezes, conflitual e tensional, nos territórios de Porto Alegre por eles sugeridos.

\section{Voz 1: Com minha bíblia, nada temo!}

Cornelia: Tudo bem, Vó?

Vó Santa: Tudo, minha filha, vão entrando.

Cornelia: Conhece este menino?

Vó Santa: Desde pequenininho. Eu criei ele, o irmão dele.

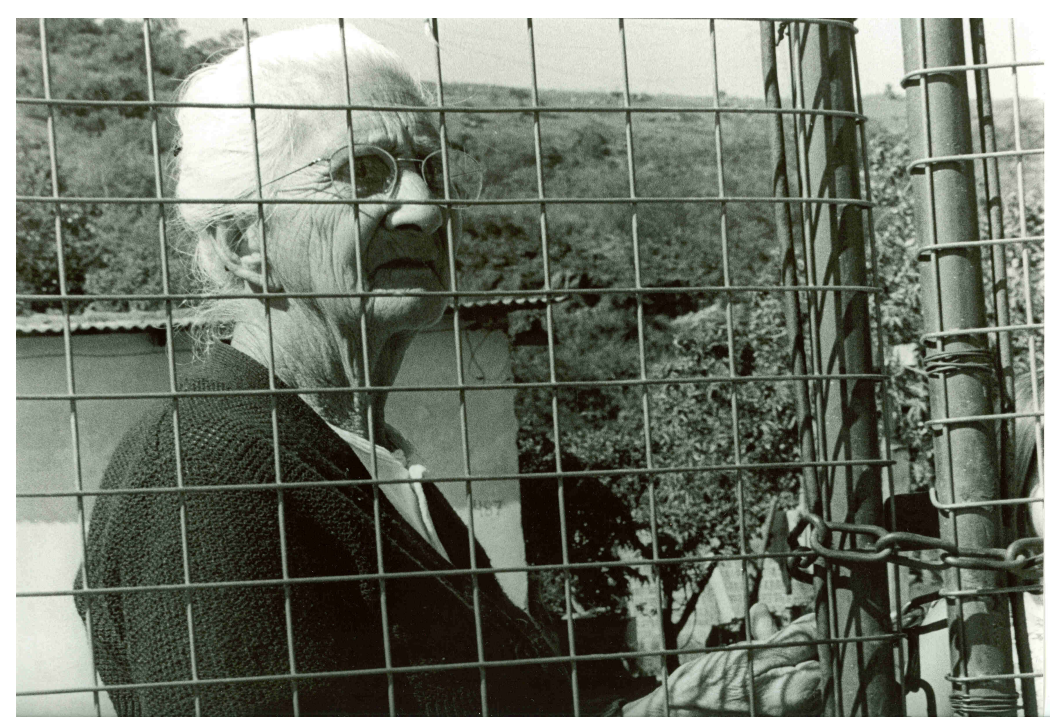


Vó Santa, como gosta de ser chamada, está referindo-se a Felipe Stella, pesquisador de iniciação científica do Navisual $^{3}$ que mediara a oportunidade de entrevistá-la naquele inverno de 1999. Faxineira, moradora do Bairro Agronomia, teria 80 anos de idade. Relatada em diários de campo, sua trajetória pelo aluno revela uma migração rural para Porto Alegre ainda jovem. Aceita ser novamente entrevistada "sobre sua vida", mesmo já sendo uma interlocutora importante na pesquisa sobre crise e medo na cidade de Porto Alegre por nós desenvolvida desde 1997. Nesse dia, na sua casa de alvenaria de dois cômodos, aceita ser filmada. Recebe nossa equipe abrindo o portão gradeado e fechado com cadeado, conforme mostra a fotografia.

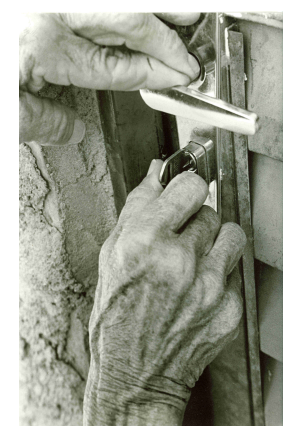

Entre cuidados domésticos, lava a roupa e cuida de um neto de dois anos de idade. Para ser filmada, escolhe sentar perto da mesa em que pousa uma bíblia. Diz estar "pronta para nos contar sua vida". Filmamos.

\section{Voz 2: A gente não tinha medo}

Thaís Vieira, bolsista de iniciação científica do BIEV, finalizava sua pesquisa em 2000 sobre trajetória de mulheres idosas na cidade de Porto Alegre. Uma de suas informantes, Orientina, era sua avó.

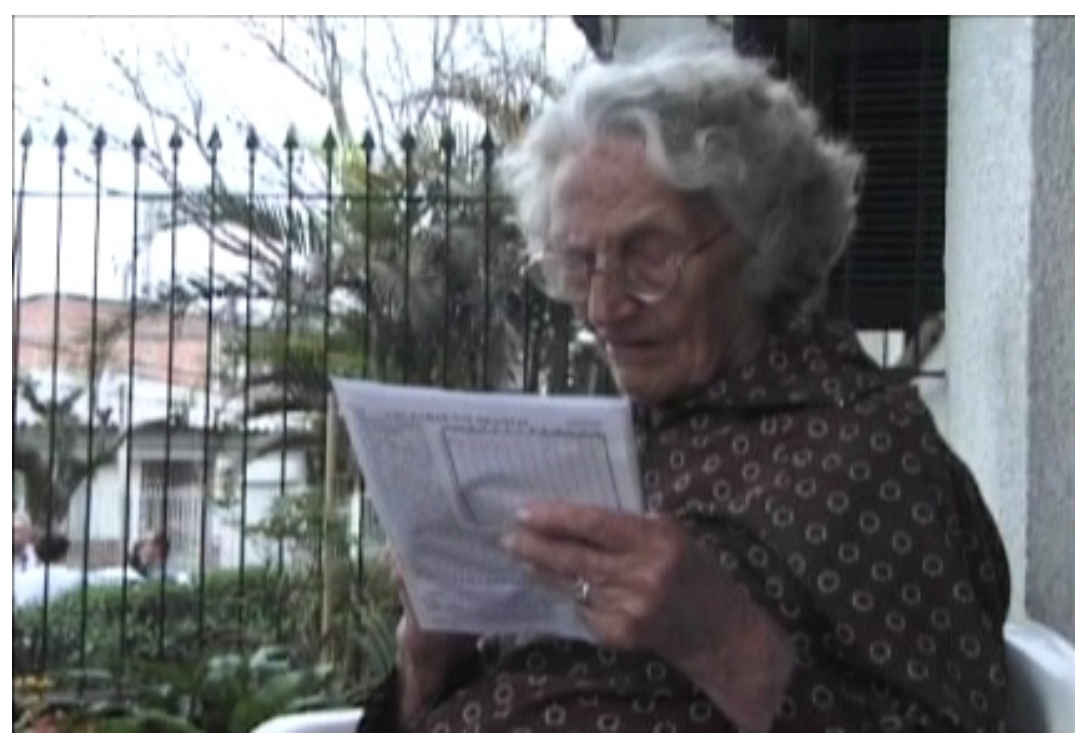

\footnotetext{
3 Núcleo de Antropologia Visual do PPGAS IFCH UFRGS, coordenado por Cornelia Eckert.
} 
$\mathrm{Na}$ época da entrevista, residia em bairro popular numa casa de alvenaria onde criara seus filhos. Acostumada com a pesquisa da neta, cede a entrevista em sua casa para "para ajudar a pesquisa" ao "contar sua vida" em Porto Alegre, então nos seus 78 anos de idade.

\section{A emergência do tema do medo na antropologia urbana no Brasil}

Entre os anos de 1992 (Cornelia) e 1993 (Ana Luiza), havíamos retornado de nossos programas de doutoramento na França, onde havíamos tratado sobre a crise nas cidades de indústrias tradicionais (Cornelia) e a estética da desordem no processo fundacional das cidades no sul do Brasil (Ana Luiza). Na perspectiva de seguir na interface das linhas de pesquisa de antropologia urbana e imagem, elegemos como um dos temas prioritários a problemática do medo e da insegurança na cidade de Porto Alegre através de um Projeto integrado Estudo antropológico sobre memória coletiva na cidade, as formas de sociabilidade, as trajetórias de vida e os itinerários de seus habitantes. Com o objetivo de circunscrever o tema, na época, iniciamos um inventário das reportagens em imprensa e televisão sobre o tema do medo. As diversas mídias alardeavam o problema da violência urbana no Brasil. Em Porto Alegre, não era diferente.

\footnotetext{
Jornal Zero Hora, Porto Alegre, domingo 10 de outubro de 1993. p. 34. Artigo Violência muda hábitos e conviç̧ões: "Com medo de repetir momentos de angústia, a população se defende com armas e trancas e altera comportamentos. As mudanças de comportamento são regidas por atos de violência tão diferentes como o roubo de um tênis, o furto de um carro ou uma tentativa de estupro... No dia 24 de abril, um casal de idoso é assaltado na sua casa. Roubam dólares e jóias. A senhora passou a ter crises de angústia, chora muito, apresenta problemas cardíacos e só dorme se os familiares ficam até tarde da noite na residência. $\mathrm{O}$ casal decidiu se mudar para um apartamento.
}

No nível político, a cidade de Porto Alegre, numa sucessão de gestões administrativas lideradas pelo "Partido dos Trabalhadores" (PT), conhecia como demanda recorrente nas reuniões de representantes do Orçamento Participativo a solicitação por maior segurança nas ruas, nos bairros, nas escolas, nos ônibus, a qualificação dos equipamentos urbanos de prevenção como iluminação e assédio policial constante. Logo os discursos dos candidatos a cargos administrativos municipais passaram a ter o slogan de maior segurança como carro chefe em programas eleitorais em face de um cenário de "aumento de criminalidade" 
alardeada por instituições estatísticas públicas e privadas. A cidade vinha sendo, assim, construída pelos discursos mediáticos como um "porto pouco seguro" e nem tão alegre. A estruturação de uma secretaria de segurança pública do Rio Grande do Sul mais moderna tornou-se prioridade para projetos de governo estadual e municipal. Estas passam a orientar (manuais de segurança) por mudanças de comportamento nas formas de viver os espaços públicos a partir de campanhas em folders e em portais eletrônicos institucionais como www.sjs.rs.gov.br, no qual a polícia civil, por exemplo, estabelece orientações preventivas. Suas orientações motivam para a formação de um cidadão alerta, prudente, vigilante, que mesura cada ato como cuidado necessário para evitar riscos à sua vida e ao seu patrimônio.

As mudanças de hábitos coletivos na cidade (dicas de segurança) são precauções apreendidas pelos cidadãos para a diminuição da vulnerabilidade e exposição ao fator de risco evitando atitudes "facilitadoras" de atos criminosos. Em particular, a paisagem arquitetônica e urbana de Porto Alegre transforma-se radicalmente em decorrência do medo da violência. Na esteira desse processo, proliferaram grades, porteiros eletrônicos, guaritas, arames e cercas elétricas, circuitos de alarme internos e externos não só em bairros identificados como "enobrecidos", mas também em bairros populares os moradores e pequenos comerciantes recorrem a grades e cercas a fim de dificultar roubos e assaltos cada vez mais freqüentes.

O que assistíamos nos noticiários da época era, portanto, a crescente configuração da cultura do medo na cidade de Porto Alegre. Compreendia-se que o mundo da vida cotidiana dos habitantes urbanos nas grandes metrópoles contemporâneas do Brasil expunha cada vez mais ao citadino a desagregação das relações sociais em face dos discursos da insegurança e da vulnerabilidade, ameaçando os projetos de construção de um tempo ético fundado na perspectiva de valores de reconhecimento e de responsabilidade, gerando então, nos termos de Paul Ricoeur (2000), a desconfiança na cultura e descrença de uma continuidade social.

\section{De imagens e conceitos: a configuração}

Com o projeto "Antropologia do cotidiano e estudo das sociabilidades a 
partir das feições dos medos e das crises na vida metropolitana", realizamos uma série de exercícios etnográficos no contexto da cidade de Porto Alegre. O tema tratava da memória dos habitantes no cotidiano urbano sob o enfoque da cultura do medo, face às situações de crise e violência no mundo contemporâneo. Entrevistas realizadas nas residências de alguns moradores consolidavam-se nas observações de situações vividas no cotidiano urbano porto-alegrense por seus moradores nos mais diversos bairros. Tal prática mapeava uma pluralidade e heterogeneidade de experiências do viver urbano entre os habitantes de Porto Alegre, ordenadas a partir do sentimento de segurança ou insegurança nas trajetórias construídas por eles na cidade. O compartilhamento de situações cotidianas e a participação em entrevistas resultaram no consentimento de filmagens e, aos poucos, entre alguns dos entrevistados, surgiam os narradores privilegiados que iam tecendo suas narrativas a respeito dos antigos e dos atuais territórios de adesão ou evitação em Porto Alegre, situando suas memórias vividas "de outros tempos" no interior das transformações pela qual passava a cidade.

Em decorrência das etnografias desenvolvidas cujas imagens (visuais, sonoras, escritas) vinham sendo reunidas no corpo do Projeto integrado, criamos, em 1997, o Projeto Banco de Imagens e Efeitos Visuais/BIEV, orientado para formação de coleções etnográficas a partir dos acervos de imagens que tínhamos reunido sobre o patrimônio etnológico e a memória coletiva em Porto Alegre. Dessa forma, as imagens produzidas sobre as feições da crise e do medo entre outros eixos temáticos foram construídas pelos pesquisadores em coleções para consulta na base de dados do $\mathrm{BIEV}^{5}$ e na sua homepage www.biev.ufrgs.br. Os isomorfismos presentes a tais imagens fizeram com que repensássemos as formas das experiências biográficas relacionadas ao cenário do medo na cidade desde os estudos da duração e do tempo nas modernas sociedades complexas. O termo cunhado ao longo da referida pesquisa - etnografia da duração ${ }^{6}$ - resultaria, assim, no tratamento da memória narrada pelos habitantes urbanos desde suas experiências vividas na cidade como conhecimento de si e do mundo a partir do trabalho de recordar e da tessitura dos sentidos do medo encadeados no presente.

\footnotetext{
4 Em 1996 o Cnpq nos contempla com uma bolsa de produtividade em pesquisa para o desenvolvimento deste projeto.

5 A sede do BIEV situa-se na sala 108 do Instituto Latino-americano de Estudos Avançados/ILEA/UFRGS, Campus do Vale.

${ }^{6}$ A etnografia de duração é projeto de pesquisa proposto a partir das teses de doutorado das autoras e publicadas em Koury (2000) inspiradas na obra de Gastón Bachelard A Dialética da Duração (1988).
} 
O que equivale a dizer que, no plano dos estudos da memória para a compreensão dos territórios da vida urbana, entendíamos que os habitantes das grandes cidades não recordam suas experiências "por simples repetição" do vivido, pois desde suas lembranças devem compor seu passado, uma vez que toda vida humana é a narração, "não a recitação" (Bachelard, 1988:51).

O uso de outras linguagens além da escrita, tais como a do registro de imagens em movimento, imagens fixas e imagens sonoras nos estudos da memória coletiva como parti pris da prática da etnografia da duração, criou excelentes oportunidades para se pensar novos processos interpretativos para a produção do conhecimento antropológico sobre as dinâmicas sociais e culturais no contexto urbano. No processo do estudo das feições dos medos e das crises na vida metropolitana desenvolvido no interior do BIEV, a representação etnográfica do viver urbano nas grandes metrópoles passa, então, a ser cotejada com outras formações discursivas tais quais as dos meios de comunicação segundo a preocupação de desdramatizar as disposições morais de uma cultura do medo que propaga limites de sociabilidades e incrementa a segregação espacial e a discriminação.

Ao se aderir aos jogos de imagens que narram os habitantes da cidade sobre a violência urbana, sobre suas experiências de vitimização e sobre os gestos de busca de proteção ao patrimônio e da pessoa física, acabamos por reconhecer, nos relatos e entrevistas realizados com inúmeros moradores de bairros populares e de camadas médias, uma referência constante à condição de vulnerabilidade do viver a cidade, a qual se mesclam as acusações aos órgãos públicos pela inoperância de suas propostas de políticas de erradicação do crime. Disso resulta a imagem da violência urbana cuja matriz, simbolicamente compartilhada, seria a decadência das grandes metrópoles contemporâneas e a degradação dos valores éticos, o que geraria a crise da civilização urbana. Uma imagem da crise para a vida citadina e de suas feições que tende a situar a violência, nos termos de Eduardo Soares (1995:1), numa linguagem compartilhada, a partir do qual foi pensado os limites da sociabilidade pública e privada em nossos estudos nos territórios urbanos de Porto Alegre, a sua crise e suas possibilidades, reconhecendo-se o medo e a insegurança como determinismos socializadores cada vez mais presentes no convívio urbano.

Pelo estudo etnográfico, os relatos dos habitantes nos informavam sua 
adesão a estratégias de maior proteção, seja pelo consumo em um mercado de segurança com a proteção de suas casas e carros, seja pela mudança de hábitos e estilo de vida, levando-nos a pensar o interior das coleções etnográficas do BIEV o medo como "valor" presente nos processos de representação social sobre a vulnerabilidade pessoal em face do aumento indiscriminado da violência urbana, obrigando os habitantes a espreitar suas práticas sociais num quadro de probabilidades de riscos, o que empresta a imagem de sujeição a formas individualizadas de vitimização.

\section{Dispositivos do projeto fílmico}

Em 1999, através do projeto de realização do documentário $A$ cidade sitiada, participamos de um concurso para a produção de documentários etnográficos através da AECI (Agência espanhola de dotação de recursos para a América Latina) e obtivemos o prêmio para a finalização de um vídeo etnográfico com base na pesquisa que vínhamos realizando. De todas as trajetórias sociais e itinerários urbanos pesquisados até o momento, optamos por nos limitar a dois personagens paradigmáticos em suas experiências urbanas no que tange as narrativas documentário sobre as experiências de viver sentimentos de vulnerabilidade, insegurança e medo na cidade de Porto Alegre.

O documentário $A$ cidade sitiada de que trata este artigo, foi finalizado em 2001, tendo sido realizado em sistema NTSC, com duração de 30 minutos, com direção das autoras, tendo como operador de câmera o antropólogo Rafael Devos, na ocasião bolsista de iniciação Cientifica/CNPq. Ao todo foram realizadas dez horas de gravações de entrevistas, em formato mini-DV.

Pela análise das trajetórias sociais e dos itinerários urbanos dos personagens do documentário - e a partir das entrevistas transcritas e dos diários de campos adentramos os elementos estruturais de suas narrativas biográficas: a migração de cidades de menor porte ou mesmo de áreas rurais para a capital na busca de trabalho. Uma vez em Porto Alegre a experiência de uma trajetória de mudanças residenciais entre vilas ou bairros eram orientados no passado em geral pela proximidade do trabalho ou pela acessibilidade a compra ou aluguel de moradia, e, mais recentemente, experiências de mudanças mais freqüentes como estratégias de obter maior proteção para seu patrimônio e maior segurança pessoal no contexto metropolitano, seja pelo consumo de um mercado de segurança, seja pela 
mudança de hábitos e estilo de vida. Observávamos, assim, desde as coleções reunidas na base de dados do BIEV e a realização do documentário, a ação cotidiana dos habitantes na busca de diminuir suas vulnerabilidades à criminalidade na cidade no âmbito das teorias reflexivas do risco, fenômeno correlato ao processo da proliferação discursiva sobre o medo social pela imprensa, no aumento do mercado de segurança, pelas resoluções de políticas públicas, aproximando-nos, por exemplo, de Mary Douglas (1992), que afirmava vivermos em uma sociedade de riscos, reveladora de uma nova cultura individualista relativa ao quadro de determinações abstratas e universais onde os riscos se tornam fatos sociais.

\section{Trajetórias narradas}

Conhecíamos Marlene e Augusto, ambos participavam de alguma forma da rotina familiar de membros da equipe. A proximidade facilitou a interlocução e o consentimento para as filmagens.

Marlene se colocava para nós como uma voz de grupos populares em sua biografia singular. Dificuldades de toda ordem marcada pela carestia e pela discriminação. Augusto, em seu estilo de vida, dava o tom da tendência de famílias de camadas médias transferirem-se para condomínios fechados. Outros hábitos em sua rotina simbolizavam o padrão de consumo desta pertença como sua adesão a uma rede de aposentados que se exercitam regularmente em parque revitalizado e onde se sociabilizam para o consumo coletivo do chimarrão e muita conversa. Atividade esta diurna, numa condição de policiamento e em territorialidade que virou marco do lazer de grupos médios.

\footnotetext{
Desde nenê minha vó nos cria, nos criou porque o meu pai era uma pessoa assim... meu pai era alcoólatra, sabe, meu pai era uma pessoa assim que saia de casa e levava duas, três semanas sem aparecer. Quando aparecia em casa, ele queria matar a minha mãe... ele incomodava. Queria bater em todo mundo, aí eu ficava sentada no meio da rua. Minha vó chamava a polícia, dava tiroteio... Era a

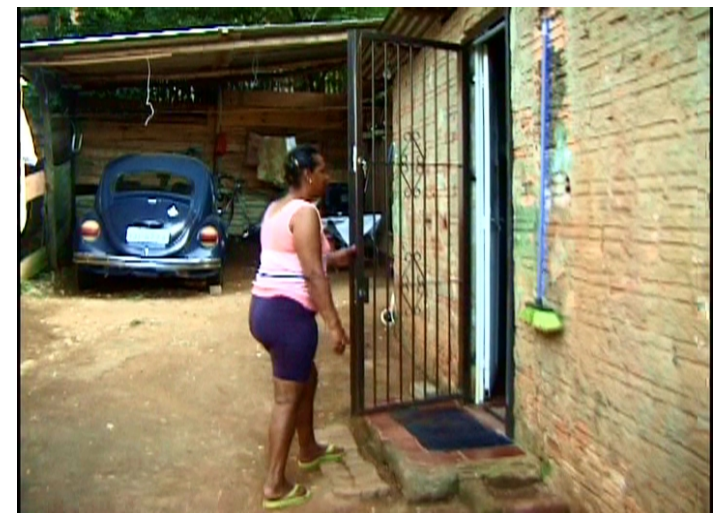
minha mãe e a minha tia correndo pelo meio da rua afora com a gente correndo fugindo deles.... eu carregava meus caderno dentro dum saquinho plástico e ia pro
} 
colégio de tamanco, meu tio botava uma sola de borracha em baixo pra nós não faze barulho, é pra nós não faze barulho. Eu nunca tive assim uma infância duma criança brincar, normal como hoje em dia todas as criança brincam, nós nunca tivemos uma boneca, sabe. eu sempre trabalhei pra ajudar a minha vó sabe, eu sustentava a minha avó. Então todo o dinheirinho que eu ganhava, era pensando ajudá a minha vó, porque minha vó naquela época não era uma pessoa aposentada.

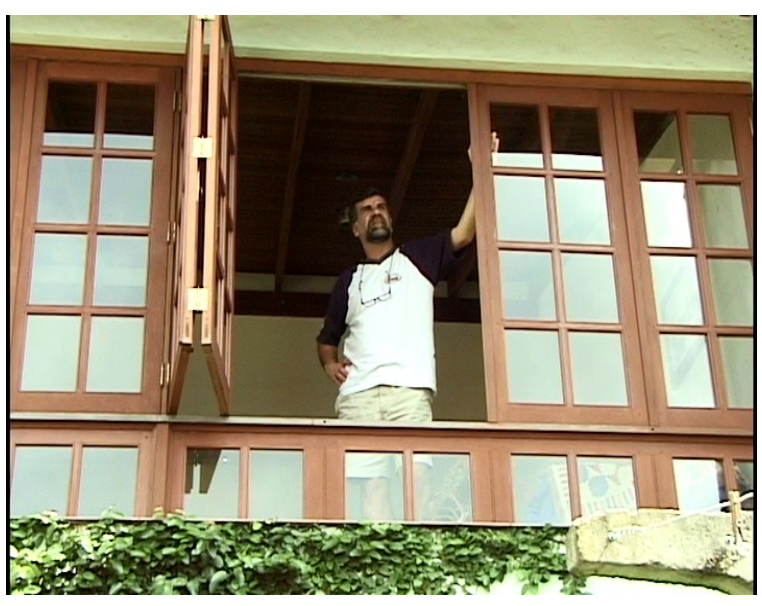

Eu perdi meu pai quando eu tinha seis anos de idade. Então, o pai era engenheiro e tudo... Vamos dizer, ele ganhava hoje o equivalente a $4.000,5.000$, e no outro dia a mãe estava com meio salário mínimo de pensão e com cinco filhos. As gurias, uma estudava no Sevigné, outra no Bom Conselho, tiveram que sair do colégio e trabalhar. Começaram a trabalhar uma com 16 anos outra com 17. Eu comecei a

trabalhar com 18 anos no quartel. Depois com 19 anos eu já estava trabalhando, o meu irmão também... eu dos nove aos 17 anos, eu estive interno num colégio. O meu número era 29 , eu usava o número em tudo, meia, cueca... O meu número me perseguiu durante sete anos e meio. Por exemplo, batata frita, ovo, era impossível fazer para duzentos internos. Então para mim ovo era coisa de rico

\section{Dilemas da estetização do medo como intriga na narrativa etnográfica}

O desafio do vídeo etnográfico a ser produzido residia em seu caráter mais "conceitual", ou seja, precisamente, na forma como ele seria capaz de expressar as quebras ocasionais e voluntárias e/ou nucleares e derivativas de significações culturais para o tema das feições da crise e do medo em Porto Alegre, fruto do encontro etnográfico do antropólogo com seus sujeitos de pesquisa, fazendo concordar, ao final de uma sucessão temporal, o testemunho documental de tais personagens com a experiência do próprio ato social que se está retratando.

Neste sentido, torna-se evidente que para nós o filme etnográfico pode atribuir ao antropólogo o papel de "criador de intrigas" de "fazer surgir o inteligível no sensível”, emergir "o universal do singular, o necessário ou o verossímil do episódico" (Ricoeur, 1994). Estas reflexões aplicadas ao processo de realização de uma etnografia visual conceitual da duração, por exemplo, supõe, por parte do antropólogo, a exploração das "artes do ilusionismo" oriundos da linguagem cinematográfica, uma vez que o filme etnográfico resultaria menos da natureza fragmentária do tempo do que da sua negação pela via da construção de 
uma inteligência narrativa, fundamento dos próprios jogos da memória.

Com base nos escritos de Paul Ricoeur (1994) sobre tempo e narrativa, ousamos insinuar que o processo de construção do vídeo etnográfico fundou-se na tentativa de ordenação diferencial de, no mínimo, três modos de restaurar, através da imagem-movimento, o fenômeno da duração no interior das narrativas do medo e da crise fornecidas pelos personagens do documentário, seguindo-se sua feição intratemporal. São elas, "o tempo pré-figurado" da experiência temporal dos grupos humanos pesquisados, abrangendo o roteiro de gravação, incluindo-se aí o próprio ato etnográfico, e que se traduz no problema do diálogo entre tradições narrativas múltiplas, as "nativas" e as do próprio antropólogo; "o tempo configurado", da experiência temporal pensada a partir da trama conceitual que encerra o encontro etnográfico a ser narrado e refletido num roteiro de edição, e, finalmente, “o tempo reconfigurado", onde a experiência temporal do espectador é projetada na obra etnográfica produzida.

A possibilidade de realização de uma etnografia que configure "idéias" conceituais depende, portanto, do ato de compreensão de que a imagem fílmica está imersa no plano da imaginação criadora, possibilitando ao espectador a construção e reconstrução da matéria do tempo de forma ininterrupta, não-linear, por equilibrações sucessivas e reversíveis dos intervalos e dos instantes vividos.

Contrário, portanto, às antíteses bergsonianas, o tratamento conceitual do fenômeno da duração, pela via da etnografia visual, implicava para nós que o vídeo etnográfico $A$ cidade sitiada, deveria absorver, "nos níveis das significações culturais", o diálogo da inteligência humana de nossos narradores com a matéria perecível do tempo, ou seja, de suas lembranças de experiências vividas na cidade de Porto Alegre, de suas transformações em direção a sua paisagem; isto é, a de uma cidade de muros (alusão a Caldeira, 2000).

\section{Extratos do roteiro de edição}

$\mathrm{O}$ cerco à cidade, os temores e as inseguranças. As paisagens interiores. Imagens da cidade à tardinha (mais e mais nuvens passando). Falas das velhas senhoras no papel do coro (plano fechado) .

Vó Santa: Agora já está tudo diferente, né? Porque agora tem vila aí em cima, mudou muito né? Em seguida eles assaltam as casas... a gente tem que ter medo, hoje em dia a gente tem que ter medo de tudo, né? Tem que se cuidar muito, mas aqui nunca aconteceu nada graças a Deus, comigo não, mas tem acontecido com, os outros, a gente vê o sofrimento dos outros. 
D. Orientina: É, meu Deus do céu, a gente tá sempre preocupada com os netos, bisnetos, sempre preocupada. Mas isso é da vida, é da humanidade, fazer o quê. E feliz de quem se preocupa com os seus!

As falas dos protagonistas intercalam-se com imagens de vertigem na cidade. A cidade à tardinha e seu clima opressivo - jogo de planos fechados de rosto de pessoas - closes, o olhar da câmera pelas grades, muros, vegetações.

Marlene: Tu dá conselho, sabe: - filho é assim, é passado... Eles acham que já tem uma idade - Ah! Não dá nada mãe! E tu, - Filho! olha de noite na rua, não anda de noite na rua! Olha os documento! Tu que fica dentro de casa, tu fica imaginando mil e uma coisa, onde que tá meu filho, meu Deus? Será que tá morto? Será que atiraram? Porque fim de semana é um tiroteio só aqui nessa vila né!

Augusto: Tudo fica centralizado no Felipe, porque é ele que dirige o carro, então é ele que tem que buscar as gurias nas festas. As vezes ele está numa festinha boa, as duas horas da madrugada tem que sair pra buscar as meninas.....A gente pensa que está seguro, mas as vezes não está.

Marlene: Aqui que eles assaltam.... Esse meu vizinho aqui do lado, o armazém dele agora tá com grade, ele foi assaltado. É daqui da zona mesmo. Aqui essa semana passada não entraram aqui? .... Chega uma certa hora tu tem que manter as porta fechada porque eles tão entrando. Tu não tem mais segurança. A viatura tem que andá é de noite aqui, elas andam de manhã, de manhã quando eu tô na parada do ônibus, passa duas, três viatura, fazê o que, os bandido tão dormindo essa hora, eles já assaltaram de noite né?

Augusto: A opção do condomínio é agora depois que eu retornei bem mais tarde para Porto Alegre.... Eu não sei se é porque a gente se assusta um pouco... Porque tu pode morar também numa casa... Ter uns cachorrinhos meio da pesada e pagar menos que um condomínio, né?... Ipanema, um lugar bonito...

Marlene: Eu desço de noite aqui, nunca ninguém me fez nada, que toda, esses guri, essa gurizada toda, que tudo se criou comigo aqui na vila, que estudou junto comigo, são tudo assaltante, sabe, marginal. Eu nunca deixei de cumprimentar, agora tu querer dá uma assim ó, de posuda pra eles, deu pra ti, deu pra ti que eles te marcam, na próxima, eles te pegam.

\section{O que é o tempo da crise, tempo do medo?}

Sob o ponto de vista geral da compreensão narrativa que encerra a produção de uma obra etnográfica, vale assinalar, aqui, o "potencial hermenêutico" que ela contempla. Ao incorporarmos a estrutura semântica da ação narrada pelos personagens do documentário, aos recursos de simbolização da montagem em paralelo, revelamos o seu caráter temporal "construído".

Evidentemente este tratamento dado na edição do documentário contempla, necessariamente, a explicitação do conjunto de operações intelectuais através das quais o antropólogo faz a experiência temporal do medo e da crise relatada por seus personagens elevar-se do "fundo opaco do viver, do agir e do sofrer humano" (Ricoeur, 1994), traduzindo-a para um leitor que a recebe e, assim, muda seu ponto de vista sobre o sentido de suas próprias lembranças. 
Neste ponto, nos filiávamos a proposta de David Mac Dougall (1992) sobre o processo de conceitualização que subsidia a produção de uma etnografia visual de idéias para quem esta se traduziria na arte de narrar, ou seja, na atividade do "tecer da intriga" decorrente de operações cognitivas específicas através das quais o antropólogo extrai de uma simples sucessão de acontecimentos apresentada por uma trajetória social ou um itinerário urbano uma configuração de sentidos, construída na ordem da linguagem cinematográfica, através de suas formas simbólicas expressivas.

\section{Extrato do roteiro de edição}

Imagens da cidade de Porto Alegre à tarde (mais e mais nuvens passando). Algumas imagens (planos mais fechados) da cidade à tardinha.

\section{Voz do jornalista na TV, imagens de noticiário televisivo}

... o crime perde força, um dos chefões foi pra cadeia... 10.000 presos, especialmente na Casa de Detenção... Eles forneciam informações para planos do PCC... Os 20 bandidos chegaram atirando. Armados com fuzis, encapuzados. A polícia apreendeu armas e este suspeito... Quatro granadas, uma dinamite e muita munição.

\section{Extrato do roteiro de edição}

As feições da crise e os processos de vitimização. Imagens da cidade à tarde (mais e mais nuvens passando). Algumas imagens (planos mais fechados) da cidade de Porto Alegre à tardinha.

Falas das velhas senhoras, o coro, (plano fechado no rosto das comentaristas, ao fundo).

D. Orientina: “..... era uma vida bem simples, né, bem pacata, mas era... num ponto era melhor, não havia violência como há hoje, né. As crianças saiam, brincavam de noite na rua, a gente sentava na calçada. Até tarde da noite. Vai sentar na calçada hoje botam pra dentro com cadeira e tudo né. Deus o livre, vai ficar com a casa aberta sentada na rua, tá pedindo pra ser assaltada né?"

Vó Santa: Eu tenho um neto que até hoje tá na penitenciária do Jacuí lá, que ele já é avô e ele começou a ser preso desde os doze anos. A gente sofre, eu não gosto nem de falar. Desde o começo em que ele caiu, ele caiu de mensageiro dos traficantes, e porque ele era gurizinho ele ia como mensageiro, porque ninguém ia tocar nele, né?““

As falas dos protagonistas intercalam-se com imagens da cidade em movimento. A cidade, o movimentos de pessoas e clima de insegurança (jogo de planos fechados)

Marlene: Eu acho que a minha vida acabou assim, a partir do momento, que fez um ano agora 23 de abril, que eu tive um filho preso... Não que meu filho é um marginal, que é assaltante, não. Meu filho ficou preso, três meses. Três meses até o advogado conseguir provar a inocência do meu filho. ...

Augusto: Era bom caminhar a pé, a noite. Muito melhor que essa 
criançada, que pega o carro e eu fico louco de medo. A gente andava tranqüilo.

Marlene: se tu quiser conhecer o inferno, entra dentro daquele Presídio Central, que eu tive que entrar. Eu tive que fazer carteira, tive que fazer carteirinha pra entrar dentro daquele Presídio Central. Eu sei o que eu sofri, Ana. Três meses que pra mim parece que foi uma eternidade. Três meses.... $\mathrm{Eu}$ sofri dentro daquele presídio. Acabou com a minha vida, Ana. Acabou com a minha vida.

Augusto: O bairro Menino Deus é muito bom, você sai, não precisa carro. As vezes nem o ônibus, pode andar a pé pra tudo que é lado... mas tu não tem mais aquela liberdade do ir e vir, né?

Marlene: Como diz o ditado: quem vai pra delegacia, quem vai preso é vagabundo, negro e ladrão. Pobre é que vai preso e negro, como diz o Ratinho ali, e vagabundo que vai preso.

Augusto: Por exemplo, se eu tenho que ir ao teatro, tenho que ir de carro... Eu não posso chegar e ir num barzinho. Eu vou tomar um aperitivozinho e não dá, eu tenho essa dificuldade aqui.

Marlene: É cada vez pior.... Negro não tem chance pra nada..., pra nada, só o que eu te digo. Pra nada... me revolta isso aí, me revolta...

Augusto: Tem, ouve os tiros aqui... às vezes se ouve sim. Mas o perigo eu vejo mais pro adolescente... O meu irmão mora aqui perto também, tá com vontade de se mudar. A guriazinha dele tem 14 anos, as vezes a guriazinha dele vai numa praça, aquela praça é perigosa, aquela praça tem um pessoal se dopando. ... Ela sai e ali tem os marginalzinhos que querem ser amigos do teu filhinho também, ou passar droguinha pra ele.

Marlene: Negro não tem vez em emprego, não tem mesmo, porque se tu vai um branco e um negro procura um emprego, vamos dizer, são duas vagas né, o negro vai procura o emprego, o que é que eles vão fazer? Eles vão dá a vaga pro branco, negro é posto fora. Agora eu não sei por que.... Que eu acho que a gente é um ser humano, todo mundo somos iguais, que eu acho que se nós morrer nós vamos fedê tudo igual.

Augusto: É um receio horrível, é medonho. O próprio João XXIII (Colégio), ele teve que fechar as portas pra não deixar os adolescentes sair, porque ou eles iam pra essa praça ali ou uma praça mais perigosa ainda, mais perto da vila Cruzeiro, porque é uma beleza pro marginal pegar uma criança que tem dinheiro.

Marlene: E o meu guri, o Fabiano que tá com vinte e dois anos, que ele ficou cinco anos no quartel, as vezes ele descia na dezessete aqui, a polícia abordava ele e botava ele na parede. Ele dizia assim: Eu sou militar! Eles não querem saber, sabe. Sabe, dava-lhe soco, pontapé, sabe?

Como pode se perceber no extrato acima transcrito, nossa intenção no documentário $A$ cidade sitiada foi a de explorar as modalidades de narrativas apresentadas por nossos personagens centrais da estória adotando-se os relatos de suas experiências de vulnerabilidade e medo agenciadas como fatos (seguimos Ricoeur). O documentário é então uma obra conceitual sobre a intriga do medo pela descontinuidade que infere sobre a ritmicidade da vida cotidiana, considerando-se aqui no caso que toda a lógica do próprio pensamento, científico ou não, que pensa a distensão temporal não escapa as formas simbólicas produzidas pelas culturas humanas.

A produção de filmes documentários cuja preocupação tange os jogos da 
memória e seu tratamento conceitual, na linha da argumentação adotada, exige, portanto, que se atribua, primeiramente, às imagens captadas e registradas em campo o status inicial de um conjunto de representações conceituais, podendo evocar as ações e intenções humanas. Posteriormente, tais imagens sujeitas a manipulação do etnógrafo na produção de um documentário, sofrem uma alteração qualitativa ao comportarem uma "abstração refletidora" a partir do processo de produção de um roteiro de edição, momento em que o antropólogo confronta-se com o desafio de estabelecer o pertencimento da ação narrada a um conjunto de traços estruturais de uma dada ordem simbólica, portanto, cultural.

Para assegurar um mínimo de concisão ao relato etnográfico seguimos passo a passo os três níveis da operação mimética (mímeses I, II e III) da ação propostos por Paul Ricoeur em seus estudos sobre o tempo no interior da construção narrativa, quais sejam: os tempos da pré-figuração, configuração e reconfiguração, respectivamente, aplicados as etapas de realização e produção do documentário, ou seja, da pesquisa de campo e da elaboração do pré-roteiro de entrevista até finalmente se atingir a construção final do roteiro de edição.

Tais tempos narrativos transformaram-se em importantes mediações simbólicas constitutivas do ato de narrar e, como tal, da própria experiência compreensiva do fazer a pesquisa etnográfica em parceria com nossos sujeitos da pesquisa. Através da adoção desta estratégia, o ato narrativo sobre as feições da crise e do medo apresentadas por tais sujeitos passam de um tempo pré-figurado da ação destes personagens na cidade de Porto Alegre, em suas trajetórias sociais e itinerários urbanos (tempo do vivido presente a mimese I), para um tempo configurado simbolicamente pela composição narrativa, a do antropólogo na situação de encontro etnográfico com o outro, diálogo restaurado desde o tratamento das linguagens audiovisuais (o tempo "figurado-com" estrutural da mimese II), até finalmente se atingir o tempo re-configurado que encerra a ação de comunicar uma experiência narrada a outrem (o que caracteriza o tempo da alteridade, da mimese III).

Apresentar os dilemas, as tensões e as negociações do mundo urbano e da ação dos personagens diante de suas trajetórias e itinerários na cidade de Porto Alegre como elementos verossímeis de um viver urbano pelo olhar da câmera; recolocar visual entre tais personagens como habitantes de uma grande metrópole, mergulhar o espectador no mundo urbano desde as feições discursivas sobre o 
medo e a crise urbana; desvendar as sutilezas de nossos sujeitos da pesquisa nos distintos espaços da vida citadina local; em suas casas e nas ruas da cidade, enfim, todas estas questões nos interrogavam sobre o lugar do antropólogo também como narrador de sua própria cidade.

\section{A reconfiguração ou a circulação de idéias: a cidade mdoerno como} campo de investigação

Podemos pensar que as cidades de fato já nasceram sob estigma das narrativas da crise como o demonstraram os sociólogos da Escola de Chicago, influenciada pelos estudos de intelectuais alemães como Max Weber ${ }^{7}$ e Georg Simmel. Nesta perspectiva de estudos e pesquisas, a cidade moderna foi traçada a partir de mapas mentais, regiões morais, áreas de pertencimento, micro-mundos sempre relacionados a dinâmicas macro-sociais, espaços individuais e coletivos, privados e públicos, situações e posições de classe e de grupos sociais que vão delineando concepções simbólicas, mundos culturais em que atores sociais pensam e agem cotidianamente.

Revoluções paradigmáticas do século XVII com o racionalismo e as transformações econômicas com o capitalismo já se colocavam como irreversíveis a cidade como locus humano por excelência com suas máximas, a pragmaticidade, o mercado, a razão utilitária, a funcionalidade, instituindo a individualidade como valor maior do social e o sujeito moderno e anônimo como símbolo maior da conquista da liberdade.

Georg Simmel, entre outros, é um dos autores que nos lega de forma qualificada no conjunto de sua obra, as definições deste homem moderno, produto do processo urbano, figura generalizante da condição urbana, ou o personagem judeu e comerciante nômade, que tem por objetivo introduzir um fator de desestabilização do meio urbano e da limitação de reagir enquanto uma comunidade tradicional neste contexto impactante que é a cidade.

Novos conceitos são elaborados ou adaptados para dar conta de processos da condição humana, como uma intensa mobilidade, a heterogeneidade, os

\footnotetext{
${ }^{7}$ Se lermos, por exemplo, o texto de Max Weber sobre a cidade, conheceremos o processo de transformações no sistema feudal, no mercado e sobre o desenvolvimento do capitalismo com seu auge no final do século XVIII e a estabilização da revolução industrial no século XIX, mas mais importante de tudo nesta tradição alemã é o conhecimento compreensivo sobre o que será este espírito urbano e capitalista.
} 
deslocamentos sistemáticos, a ascensão social, a acumulação, o consumo, novas sociabilidades, os impactos psicológicos, aspectos que conformam uma mentalidade urbana e novos personagens urbanos tão bem sintetizados na noção de reserva blasé proposta por Georg Simmel ao pensar o citadino frente as diferenciações sociais enfrentando complexos e diversificados valores que comporão as regiões morais.

Estávamos diante da tarefa de dispor os fatos vividos e narrados por nossos personagens através de seus processos de rememoração, onde o tema do esquecimento e da lembrança de situações de crise e medo se coloca como desafio para o uso dos recursos audiovisuais do próprio pesquisador em campo.

\section{Extratos do roteiro de edição}

O passado, a cidade e os medos. Apresentando o cenário e seus dramas. Imagens da cidade pela manhã (algumas nuvens passando). Algumas imagens (planos mais fechados) do cotidiano da cidade (movimentos de pessoas, carros, reformas).

Vó Santa: Eu tinha medo porque eu não conhecia o que era uma cidade, não é? então eu tinha medo, eu disparava até dos indigentes, que não, muitos fazem alguma coisa mas muitos não fazem, a necessidade cobria eles né pobrezinhos...foi de uns anos prá cá e que começou esse desespero né? De assalto de esses indigentes que assaltam as pessoas assim só por judiaria né?

D. Orientina: Aumentou muito a cidade, porque essa Assis Brasil, pra cá não era calçada, era uma poeiragem, uma coisarada, né... Mas isso, tudo assim era muito... não era o que é hoje. Era uns casebre, às vezes tinha, pedaço que não tinha nada.

As falas dos protagonistas principais intercalam-se com imagens da cidade em movimento. A cidade e seus contrastes. (jogo de planos fechados e abertos)

Augusto: Aqui é o bairro Nonoai, mas tem um pouco de Vila Cruzeiro, porque a vila Cruzeiro é logo ali. Tem a vila Cruzeiro, tem a vila Formiga... Uma das zonas é a nossa.. Aqui é um dos piores focos de Porto Alegre. ...

Marlene: Isso aqui era um matagal,.... eu limpei isso aqui. Isso aqui era tudo maricá, só tinha uma estradinha pra ti passar e uma maloquinha que tinha aqui no meio do terreno né. ... eu digo é meu né, agora eu vou lutar porque é meu.

Augusto: Aqui tem muita criançada da FEBEM, os marginalzinhos, que moram aqui no nosso bairro. Mas eles não atacam próximo à casa deles, não atacam...

Marlene: Eu sou, eu moro há 49 anos aqui, antigamente não tinha luz era só de lampião, não tinha água encanada, não tinha luz, não tinha esgoto, né. Não tinha nada, não tinha supermercado, não tinha, como é que se diz? não tinha madeireira, não tinha nada, nada.

Augusto: Eles asfaltam até as entradinhas onde eles se escondem. Eles procuram asfaltar pra polícia entrar livremente ali, que assim ele vão... vai desmantelando os focos. Mas é uma das zonas mais perigosas.

Marlene: Eles são mais bem armado do que a polícia, aqui é de doze 
minha filha....Arma de doze, doze calibre, trinta e oito. Compram, eles roubam, né, Ana, eles assaltam. Aqui que eles assaltam aqui Ana. Esse meu vizinho aqui do lado, o armazém dele agora tá com grade, ele foi assaltado.

Augusto: Eles levaram as pessoas pro condomínio em função da segurança. E a classe média alta mesmo assim optou por aquele lugar ali. E hoje, até eu acredito que a Vila Cruzeiro, com o tempo, com o asfaltamento, com saneamento básico, com tudo... Eu acho que o pobre vai ser corrido dali pela classe média alta, que aos pouquinhos vai tomando conta.

Marlene: Que segurança que tu tem? Nenhuma. Chega uma certa hora tu tem que manter as porta fechada porque eles tão entrando. Tu não tem mais segurança.

Augusto: Eu morei em Santa Cruz do Sul, Passo Fundo, Pelotas... Aí não tinha problema de condomínio, né? Mesmo em Pelotas, encontrando aquele grau de dificuldade da miséria que Pelotas tem... A gente tem problema de segurança em relação aos filhos, isso aí existe mesmo. É bem diferente do interior. No interior tu já sabe onde é que eles estão, em tal lugar e pronto.

Marlene: Essa vila aqui foi muito boa, depois que eles começaram a fazer uma limpa na cidade, aquela, aquela Maria da Conceição, que eles acabaram com aquela vila a Maria da Conceição, sabe?Faz uns anos, aí aqueles maloqueiro começaram a vim tudo pra cá, começaram a se expandir aqui na vila, aí começou os assaltos.

\section{A insustentável vulnerabilidade do ser: personagens da cidade moderna}

São inúmeros os personagens que definem a cidade como um sistema comunicativo e formas de interações de tipos diferenciados. O flâneur melancólico vaga nas multidões em Charles Baudelaire, o homem desmemoriado da vivência solitária em Walter Benjamin, o alienado em Karl Marx, o ser atomizado da auto-conservação ou o indivíduo-massa em Theodor Adorno , o homem do subterrâneo de Fiódor Dostoiévski o tipo privatista e auto-centrado de Hanna Arendt, o intimista refugiado de Richard Sennett, o narcisista de Christopher Lasch, o solitário sem identidade o zapper solitário da TV interativa dos não-lugares de Marc Augé, o homem sem qualidades de Robert Musil, a massa silenciosa de Jean Baudrillard, enfim, a literatura e a ciência humana, não cessam de refletir sobre estas personalidades ditas imagens de uma cidade como criatura da crise. ${ }^{8}$

A atitude blasé, a melancolia, a tristeza, hoje diríamos o medo, a fobia, a depressão, o stress, seria a resposta subjetiva sobre a cultura objetivante dos papéis segmentados, da dinâmica de competição das relações, das vicissitudes de evitação e estranhamento, das distâncias em face das novas complexidades no

\footnotetext{
${ }^{8}$ Estes personagens são citados por CARVALHO, Sérgio. "Lonely Sweet Home": solidão e modernidade. Dissertação de mestrado Dep. Sociologia FFLC. USP, 1995, p. 9 e 10.
} 
jogar o social.

De fato Georg Simmel em seu célebre ensaio A metrópole e a vida mental afirma que a grande conquista do indivíduo moderno foi a liberdade do anonimato na multidão e a liberdade da elaboração e busca de um tipo de espírito refinado em sua originalidade, em contraste e diferença com qualquer outro. Estamos, pois tratando do processo de construção do indivíduo moderno, que reivindica liberdade, privacidade, autonomia, a vida das metrópoles moderna.

Não é por acaso, portanto, que a modalidade narrativa empregada pelo vídeo etnográfico $A$ cidade sitiada busca se inserir, de muitas formas, nas pistas deixadas por estes estudos que abordam a cidade como lugar de conjunção de tipos sociais e valores, em perpétua redefinição, vivendo numa sociedade complexa, em espaços diferenciados, e onde os indivíduos se localizam e se deslocam de maneiras diversas num mesmo e único território, a metrópole.

\section{Extratos do roteiro de edição}

O cotidiano na cidade de Porto Alegre - entre o inferno e o paraíso. Imagens da cidade pela tarde (céu com mais nuvens passando). Algumas imagens (planos médios) da cidade e suas grades.

Falas das velhas senhoras, o coro - plano fechado no rosto das comentaristas.

D. Orientina: ... a gente não tinha medo das coisas, né. Ladrão era... só de noite arrombando janela das casas e assim mesmo era muito pouco, não tinha assim como tem hoje. Não, naquele tempo arrombavam uma... Sabe vizinha, arrombaram a loja do seu fulano, entraram pela janela." Ah, mas aquele era uma coisa um acontecimento, e era uma coisa que acontecia mas lá uma vez que outra né?

Vó Santa: ... eu passei muito medo, porque a casa era de madeira era mal fechada, mas só os primeiros tempos, depois me acostumei, porque eu ia trabaiar não tinha fechadura na porta e deixava encostada do jeito que a gente deixava ela ficava...

As falas dos protagonistas intercalam-se com imagens da cidade em movimento. A cidade de Porto Alegre e seus contrastes. Jogo de planos fechados e abertos. Jogo de imagens de bairros residências de classe média e vilas populares.

Augusto: .... Eu tive pouco tempo de Porto Alegre... Adolescência eu não tive em Porto Alegre. Dos 9 aos 17 anos era Hamburgo Velho. Vinha no fim de semana, me reunia com o pessoal da Medianeira, ali no bairro Medianeira. Jogava futebol... até as nove da noite, pé no chão, chegava com os pés com sanguezinho... isso á noite... mas também não tinha... só no Menino Deus em 65, 66, que ali na rua Marcílio Dias que começou a maconhazinha por ali, né?

Marlene: A minha mãe era doméstica, né, minha mãe sempre trabalhou de doméstica, minha vó trabalhava no colégio, no IPA, sabe a minha avó era faxineira lá do colégio IPA? Eu aprendi com a minha avó. Eu aprendi a cozinhar com a minha avó. ...eu já trabalhei em restaurante, tá, trabalhei 
num restaurante na Carlos Gomes, trabalhei num restaurante em Viamão, trabalhei na Delegacia de Menores, fazia faxina lá, limpava né.

Augusto: A ilhota era o pior bairro de Porto Alegre, assim de droga, marginalização... Por exemplo, o bairro Bom Fim sempre foi um bairro da seresta, da cultura, da música... e o Menino Deus era um segundo bairro assim, nessa parte. ..E a droga já estava começando ali, em 65, eu me lembro bem.

Marlene: Fui criada pela família da minha mãe e da minha vó né, aí com trinta e nove anos minha mãe morreu. Ai com dez anos eu comecei a trabalhar em casa, que aí a família da minha mãe me arrumo, como eles trabalhavam assim, né... lá na Glória, eu comecei a trabalha. Lá é que eu fui vê o meu sofrimento.

Augusto: Depois que eu me formei, eu fui para o interior, fiquei 17 anos no interior. Antes de ir para o interior eu morava no Menino Deus, morava muito bem, morava na Barbedo com a Getúlio... eu ia naqueles bailezinhos da engenharia, da odonto, eu ia a pé, não tinha dinheiro pro bonde, ou ônibus... E eu, os meus amigos todos...

Marlene: Eu tinha dez anos, daí dos dez anos até os doze anos, eu nunca mais vi a minha família, eu fui completamente prisioneira sabe, trabalhei numa casa, lá na Glória. Nós dormia num porão..., e passava rato desses tamanho .... assim, por cima dos pau, nós tinha que dormi naquilo ali, aquilo ali era um verdadeiro inferno...Ela não te dava o café da manhã, eu não sabia o que era tomá o café da manhã, eu só conseguia almoçar.

Augusto: É, era a opinião unânime do pessoal. Pô, a Ilhota não dá pra chegar. A Ilhota e a Baronesa do Gravataí ali, ali era pesadíssimo. Dentro, praticamente no centro da cidade. Eu não sei por que se formou esse foco de marginalização.

Torna-se então imprescindível, ao se pensar o tratamento conceitual do medo e da crise pela via de um documentário, subverter a crença que o registro etnográfico audiovisual no caso de um vídeo é parte do processo de objetivar, pura e simplesmente, as ações humanas de nossos sujeitos da pesquisa no mundo urbano portoalegrense. Em especial, quando se tem por inspiração a idéia equivocada de que a "verdade etnográfica" é algo contrário ao olhar subjetivo e ao ato passional.

No tratamento documental audiovisual para as representações da crise e do medo, tratava-se de enfrentar o desafio de reconhecer que o par autenticidade/verdade que se projeta para o caso do documento etnográfico só é possível, no caso mencionado acima, uma vez que os jogos da memória das experiências de medo, risco e vulnerabilidade vividas no contexto citadino local sejam concebidos pelos sujeitos da etnografia no âmbito de sua significação éticomoral, sem que se eliminem as indagações a respeito dos arranjos entre as estruturas cognitivas humanas e as suas significações culturais.

\section{Vida e não-vida na perspectiva dos habitantes de uma grande cidade}

Deslocando este problema para o centro do processo de realização do 
documentário o desafio passava a ser, então, compreender a emergência da moderna concepção de indivíduo e a dinâmica da vida social urbana citadina portoalegrense, na sua dimensão conflitiva, agonística, desde as narrativas de seus habitantes.

Teoricamente propúnhamos como centro nevrálgico de nosso projeto de pesquisa relacionar a noção de crise à tragédia simmeliana que consiste na atitude do vivente à produzir "a não vida". Viver a cidade contemporânea abarcaria assim a dimensão trágica de construir incessantemente sua contradição. A alteração na tessitura urbana condicionada pelo medo social converge com a mudança de forma do pensar e do viver, conforme orienta Georg Simmel (1934), para quem, na vida cotidiana, precipita-se a figura do terceiro disformante (o conflito) nos atos interativos entre os indivíduos que desenham redes de trocas que estetizam o viver na cidade em suas diferenciações e no seu princípio de individuação A cultura do medo e a violência desmesurada colocam-se, aqui, como uma dessas formas criadas pela obra humana cujo controle escapa ao seu criador e que se desforma independentemente da vontade maior de poder reconhecer a lógica da forma para a própria duração individual na história coletiva.

No ritmo da tragédia, o homem moderno faz uma aposta sobre a vida puramente como tal, deixa desenvolver uma vida sem formas (evitação de interações sociais para diminuir a vulnerabilidade em face do temor ao Outro). Simmel, indaga-se aqui se não se trataria de um projeto estéril que ao final de contas arruinaria e aniquilaria a vida que o citadino pretende preservar. Um fenômeno que reconhecemos claramente nas falas dos personagens do documentário $A$ cidade sitiada, isto é, o esforço humano pela continuidade e permanência, na luta contra a morte (social, da cultura, sua própria), contra a dissolução, numa incessante reinvenção do cotidiano por táticas e estratégias de continuar (De Certeau). O projeto de continuar se dá sobre a descontinuidade e a ruptura, como nos ensina Gaston Bachelard na sua obra Dialética da Duração (1989). A imagem do medo como destruição da vida social, tem na duração humana o reverso da descontinuidade constituída como determinismo social pela vulnerabilidade e insegurança. A cidade sitiada é sempre agregadora de trocas de sentido e táticas de permanência. Neste caso não é questão de tragédia, mas de crise. Portanto é da dinâmica da cidade a morte e o renascer, a morte que transforma. É este eterno ciclo de morrer para renascer e criar para morrer que 
identificamos como a tragédia do viver urbano. Cessar de criar, seria risco de interrupção ou mesmo de extinção de toda vida. Ultrapassa-se a não-vida pela atividade criadora (Simmel, 1934:177-207) de ultrapassar a morte e que contemplamos na forma de uma etnografia da duração.

A noção de crise em Geog Simmel tem, portanto, justamente este componente dialético da eterna transformação das relações do homem com o mundo social. Neste sentido o reconhecimento das formas da crise oriunda do medo da criminalidade e da violência no âmbito do contexto moderno consiste na vontade de ultrapassar a tragédia inerente à cultura, na sua faculdade de produzir formas não-viventes na vida. A crise procura a romper a circularidade e a dualidade da vida e das formas, do sujeito e do objeto, do pessoal e do impessoal, onde a vida estaria a serviço da forma. Denunciando sua inautenticidade (a vida a serviço da economia, do poder, por exemplo), Simmel coloca as formas à serviço da vida. ${ }^{9}$

No que tange a sociologia da forma Georg Simmel coloca a seguinte questão, “Como a sociedade é ela possível?" (How is Society Possible? American Journal of Sociology vol. 16 (1910-11). Desde aí sua obra é um esforço para responder a esta pergunta a partir da seguinte afirmação: a sociedade só é possível porque a vivemos através das interações sociais. Neste ponto Georg Simmel dessubstantiviza as formas que adotam a vida social, qualquer que ela seja, e passa a se questionar sobre as condições do acesso ao conhecimento dos seus conteúdos como na denúncia de práticas sociais disjuntivas e desagregadoras existentes no interior do Estado nação: corrupção, violência, injustiças, discriminação, desigualdades, desemprego, abusos, ilegalidades.

Podemos então circular as imagens que mostram os narradores dos medos em seus arranjos sociais de uma tragédia que assola e configura uma crise ela mesma grávida de dinâmicas de descontinuidades e continuidades, seja nos paradoxos das culturas políticas e sociais, seja pelo esforço do habitante no viver urbano em suas táticas de reinvenção a cada dia, de duração.

\footnotetext{
${ }^{9} \mathrm{O}$ viver social torna-se assim possível, "nós vivemos e agimos na e através a sociedade". A chave da questão é que nós tomamos a sociedade como uma coisa certa e nós usamos os jogos de linguagem e nossa linguagem ordinária como se os fatores, que tornam possível a sociedade, fossem evidentes. Ora Simmel nos instiga a refletir sobre o conteúdo de nossa linguagem ordinaria e mesmo a possibilidade de falar de e sobre ela, assim que de sua existência de uma maneira significativa. "Tal é a atual filosofia do vivido, que não é nada mais do que, no fundo, um instinto de morte, incapaz de produzir uma civilização qualquer. A imortalidade exige do ser humano de perenizar a vida em criando as formas mortas e impessoais". FREUND, Julien. De Max Weber a Georg Simmel, REVISTA SOCIETES, 1992 n 37, p. 222 e 223.
} 


\section{Extratos do roteiro de edição}

O cerco, os temores, as inseguranças. Paisagens exteriores - imagens da cidade de Porto Alegre à noite (céu com sombras e luzes se acendendo).

\section{Falas das comentaristas (plano fechado )}

D. Orientina: Hoje não, sai e a gente fica preocupada, né. Botou o pé pra fora não sabe se volta. Ai que coisa triste. Eu, cada um que sai eu faço uma carga de oração. De verdade. Cada um que sai eu rezo. Pra que volte sem problemas né. Porque eu acho que tem que ser assim mesmo. Só Deus pra nos salvar.

Vó Santa: Eu tenho visto muitas coisas muito perigosas, mas a gente não pode abrir a boca, não é? E não é gente pequena e gente grande e que comanda... Então a gente que é machucada da vida, que sabe o que é viver, a gente se endoça com aquela pessoa que a gente acha tudo carinhoso, tudo bom, tudo gostoso... eu acho que é por isso que eu nunca caí numa infelicidade por causa desse filhos, não é?

As falas dos protagonistas intercalam-se com imagens da cidade. A cidade e as cenas de perseguições (jogo de planos fechados e abertos. Passeios noturnos na cidade de Porto Alegre, seus personagens e cenas.

Marlene: Mas só que eu não quero que os meus filhos passam por que eu já passei na minha vida, eu já passei muita fome na minha vida, eu já passei muito trabalho na minha vida sabe, e eu não quero que aconteça ... com meus filhos, sabe.

Augusto:... a gente tem problema de segurança em relação aos filhos, isso aí existe mesmo. É bem diferente do interior. No interior tu já sabe onde é que eles estão, em tal lugar e pronto.

Marlene: É difícil, tu vê as outras criança com as coisas que, que deram, aquela coisarada e tu não tê pra dá. Eu disse pra eles, a única coisa que eu tô conseguindo dá pra vocês é a comida, e o que eu tô conseguindo e com muito sacrifício. Eu peço pra Deus, todo o dia de manhã, quando eu me alevanto, que Deus me dê força pra mim agüentar a minha jornada.

Augusto: Eu penso muito mais neles do que em mim. Por exemplo, eu e a minha mulher, nós não viajamos, as viagens que a gente fez durante esses anos todos... a gente teria condições. ... Mas sempre foi pra dar pra eles o melhor. Ah, sim, pra deixar pra eles o patrimônio.

Marlene: Devia ter nascido homem que aí eu acho que home resolvia os problemas, sabe, e eu aqui tenho que dividi, eu tenho que sê metade home, metade mulher. Problema tudo é comigo. Eu que resolvo, eu disse se eu tivé, eu nasci errado. Meu pai e minha mãe me fizeram na hora errada, eu nasci na hora errada.

\section{Semânticas das feições da crise no cotidiano na cidade}

A constante projeção dos atos, dos gestos e das condutas cotidianas nas biografias dos habitantes na cidade nos revela cidadãos em suas identidades reflexivas e nos informa sobre suas condições de construir disposições de enfrentamento à banalização da violência criminal. A conduta não é só projetiva, é igualmente prospectiva, retrospectiva de ações e pensamentos dos habitantes no fluxo do tempo coletivo. A previsão de estratégias para os citadinos surge como 
interpretação de um campo semântico repleto de sentidos conceituais para o exercício da reflexão tecida no estoque de conhecimento apreendido no vivido cotidiano como crises a serem ultrapassadas.

Os relatos de experiências de medo à vitimização aqui apresentados desde a investigação das sociabilidades dos personagens do documentário desenham, no contexto da cidade de Porto Alegre, distintas sociabilidades urbanas reorientadas pelo sentimento de insegurança, considerando aqui o conceito de "jogar o social" simmeliano, segundo o qual os indivíduos interagem ou se evitam, se encontram ou se afastam, mas sempre em ação e reinvenção.

Nesse sentido, a cultura do medo tal qual enfocada no documentário $A$ cidade sitiada coloca-se como uma síntese singular do espírito subjetivo dos habitantes de uma grande cidade com o espírito objetivo de sua cultura urbana manifesta em seus bairros e territórios, concebendo estas tensões e disposições de sentido sob o ponto de vista do "valor"10, na dinamização dessas formas de convivência. ${ }^{11}$ Nessa experiência de medo social, o sujeito é habitante de seu tempo na cidade disjuntiva que concebe as formas dos sentidos de interação: "sujeito moderno", fugaz, contraditório, paradoxal, efêmero, vulnerável, mas sempre lá, sujeito-cidade.

Percebe-se desde os trabalhos de construção dos roteiros de edição do referido documentário que a alteração na tessitura urbana vivida pelos protagonistas da estória por ele narrada condicionada pelo medo social converge com a mudança de forma do pensar e do viver, conforme orienta Georg Simmel, para quem, na vida cotidiana, precipita-se a figura do terceiro disformante (o conflito) nos atos interativos entre os indivíduos que desenham redes de trocas que estetizam o viver na cidade em suas diferenciações e no seu princípio de individuação.

Pudemos, assim, perceber no delicado processo de construção do roteiro de gravação e sua passagem para o roteiro de edição, por um lado, que a interiorização de uma cultura do medo e da imagem genérica de um Outro ameaçador para os protagonistas e comentaristas do documentário coloca-se como mais uma matéria da sociação (Simmel, 1981 e Simmel apud Moraes Filho,

\footnotetext{
${ }^{10}$ Referência a obra de Louis Dumont bem como na forma como é apropriada nos estudos de Roberto Da Matta e Luis Fernando Dias Duarte.

${ }^{11}$ A cultura nasce na concorrência de dois elementos que, isoladamente, não a contêm: a alma subjetiva e o produto espiritual objetivo como correlatos que não encontram sentido senão em sua reciprocidade (Simmel, 2006).
} 
1983), não conseguindo, entretanto, enrijecer as suas formas de interação do contínuo viver social em sua descontinuidade, seja pelas mudanças de formas no curso dos códigos sociais e dos processos histórico-políticos, seja pelos constrangimentos estruturais que afetam as práticas de tais personagens na cidade de Porto Alegre, ao longo de suas vidas nesta grande metrópole.

Por outro lado, ao se operar o tratamento diferencial das entrevistas realizadas com os personagens do documentário em questão fomos nos dando conta, progressivamente, que o vídeo em seu caráter etnográfico deveria contemplar o fato das discursividades sobre insegurança e criminalidade que construíam a cultura do medo, como imagem do viver urbano, para cada um dos protagonistas desta estória, constituía-se como sendo uma espécie de incomunicabilidade, ou desencaixe, entre o mundo objetivo e o mundo subjetivo de uma cultura urbana em processo de transformação, ou seja, contemplada desde o fluxo do tempo e do espaço.

Neste sentido, a cultura do medo e a violência desmesurada que aparece reapresentada no roteiro final do documentário revelam-se mais uma das formas criadas pela obra humana para se viver a cidade contemporânea, que, não encontrando a objetivação em conteúdo no sentido simmeliano, se desforma na tentativa de cada um dos protagonistas do documentário de se reconhecer desde a própria individuação na história coletiva de uma cidade em processo de reconstrução de seus espaços de vida coletiva.

Ao longo da pesquisa de campo, o tratamento preciso das imagens e dos depoimentos para a consecução do roteiro final de edição nos possibilitou compreender, e tentar levar o espectador a refletir, que não há uma homegeneização de sentidos na cultura do medo no mundo urbano contemporâneo, antes "retóricas", "táticas", diz Michel de Certeau (1994), uma miríade de ações, todas trazendo em si a marca da intenção humana. Assim, mesmo que atreladas a uma complexa teia de jogos de poder enunciada nas políticas de segurança e estruturas repressivas, há reinvenção nessas condutas, "formas clandestinas assumidas pela criatividade dispersa, tática e paliativa de grupos ou indivíduos já presos nas redes da disciplina" (Harvey, 1996: 197).

Antes de conceber os estilos de vida e visões de mundo dos personagens do documentário sobre o medo e as crises numa grande metrópole como respostas a malha repressiva de controle social, como denuncia Michel Foucault (1988, 
1995), na elaboração do roteiro de edição elas tornaram-se práticas da vida cotidiana, no cerne da contemporaneidade, que ordenam simbolicamente os grandes centros urbanos desde a perspectiva do tempo e o espaço por seus habitantes, e na qual aprendemos quem ou o que somos na cidade que habitamos ou que cidade somos no fluxo do tempo.

O documentário por fim é reconfiguração pela ação no mundo como obra aberta para o jogo de reinterpretações. Como uma constelação de imagens etnográficas "livre", no âmbito da bacia semântica da cultura urbana, para seu constante rearranjo e interpretações isomórficas, o documentário não encerra um saber unitário sobre a construção da cultura do medo na cidade de Porto Alegre nem é capaz de reverter a matriz de sentido que encerra o processo de reprodução da cultura do medo, apenas provocam outras intrigas a serem narradas, imagens de outras experiências. Entre concordâncias e discordâncias, o diálogo está aberto.

\section{REFERÊNCIAS PARA CONSTRUÇÃO DO DOCUMENTÁRIO E DESTE ARTIGO}

ARENDT, Hannah. A condição humana. Rio de Janeiro, Forense Universitária, 1991. BACHELARD, Gaston. A Dialética da duração. São Paulo, Editora Ática, 1988.

BAKTHIN, Mikhail. Questões de literatura e de estética (a teoria do romance). São Paulo, Hucitec-UNESP, 1993.

BOSI, Ecléa. Memória e sociedade. Lembranças de velhos. São Paulo, Queiroz ED. Ltda. e EDUSP, 1987.

BOURDIEU, Pierre. La distinction: critique sociale du jugement. Paris, Ed. de Minuit, 1979. BRITTO DA MOTTA, Alda Trajetórias Sociais de Gênero e Representações sobre a Velhice no Brasil. IV Congresso Luso Afro- brasileiro de Ciências Sociais. Rio de Janeiro, 1996.

CALDEIRA, Teresa Pires do Rio. A política dos outros. O cotidiano dos moradores da periferia e o que pensam do poder e dos poderosos. SP; Brasiliense, 1984.

CALDEIRA, Tereza Pires do Rio. A cidade de muros. São Paulo, Edusp, Ed 34, 2003.

CANEVACCI, Massimo. A cidade polifônica. Ensaio sobre a antropologia da comunicação urbana. São Paulo, Studio Novel, 1993.

CARVALHO, Sérgio. "Lonely Sweet Home": solidão e modernidade. Dissertação de mestrado Dep. Sociologia FFLC. USP, 1995, p. 9 e 10.

DA MATTA, Roberto. A Casa \& Rua. Espaço, cidadania, mulher e morte no Brasil. São Paulo, Brasiliense, 1985.

DE CERTEAU, Michel. A invenção do cotidiano: artes de fazer. Petrópolis, Vozes, 1994.

DELUMEAU, Jean. História do medo no Ocidente. 1300-1800. São Paulo, Companhia das Letras, 1989.

DIAS DUARTE, Luiz Fernando. Da vida nervosa, nas classes trabalhadoras urbanas. RJ., J. Zahar Ed./CNPq, 1986. 290 p.

DOUGLAS, Mary. Risk and Blame, essays in cultural theory. Routledge, Londres. 1992.

DUBY, Georges. Ano 1000 ano 2000, na pista de nossos medos. São Paulo, Unesp.

DUMONT, Louis. O individualismo. Uma perspectiva antropológica da ideologia moderna. Rio de Janeiro, Rocco, 1985.

DURAND, Gilbert. A imaginação simbólica. São Paulo, Cultrix, 1988.

ECKERT, Cornelia. "Questões em torno do uso de relatos e narrativas biográficas na experiência etnográfica”. In: Humanas: RIFCH/UFRGS,vol.1n 19/20 Porto Alegre, 1996-1997.

ECKERT, Cornelia e ROCHA, Ana Luiza Carvalho da. "Imagens do tempo nos meandros da memória: por uma etnografia da duração”. In: Koury, Mauro G P. (org.). Imagem e Memória: Estudos em Antropologia Visual. Rio de Janeiro, Garamond, 2000. 19-39. 
ECKERT, Cornelia. A cultura do medo e as tensões do viver a cidade: narrativa e trajetória de velhos moradores de Porto Alegre In: Antropologia, Saúde e Envelhecimento. 1 ed. Rio de Janeiro : Editora Fiocruz, 2002. p 73 a 102.

ECKERT, Cornelia., ROCHA, Ana Luiza. A vocação do etnógrafo na cidade. RBSE. Revista brasileira de sociologia da emoção, UFPB, 2004.

ELIAS, Norbert. A sociedade dos indivíduos. Rio de Janeiro, Jorge Zahar Editor, 1994.

FERREIRA, Jonatas. "Da vida ao tempo: Simmel e a construção da subjetividade no mundo moderno". In: RBCS. Vol. 15, n 44 outubro/2000. p. 103 a 117.

FOUCAULT, Michel As palavras e as coisas. São Paulo, Martins Fontes, 1995.

FOUCAULT, Michel. Vigiar e Punir. Petrópolis: Vozes, 1988.

FREUD, Sigmund. "Moral sexual civilizada e doença nervosa moderna". In: FREUD. Livro 31. Pequena Coleção das Obras de Freud. Rio de Janeiro, Imago, 1986.

FREUND, Julien. De Max Weber a Georg Simmel, REVISTA SOCIETES, Paris, 1992 n 37, p. 222 e 223.

GEERTZ, Clifford. A interpretação das culturas. Rio de Janeiro, Zahar, 1978.

GIDDENS, Anthony. A constituição da sociedade. São Paulo, Martins Fontes, 1989.

GIDDENS, Anthony As conseqüencias da modernidade. São Paulo, Unesp, 1991.

GOFFMAN, Erwing. La mise en scène de la vie quotidienne. Paris, De Minuit, 1973.

GOFFMAN, Erwing. Les rites d'interaction. Paris, De Minuit, 1974.

HABERMAS, Jurgen. L'espace public, Paris, Payot, 1978.

HALBWACHS, Maurice. La mémoire colletive. Paris, Puf, 1968.

HARVEY, David. Condição pós-moderna. São Paulo, Loyola, 1996.

LAHIRE, Bernard. Homem plural. Petrópolis, Vozes, 2002.

LASCH, Christopher.The culture of narcisism: american life in the age of diminishing expectations. New York, Mouton, 1978.

LATOUR, Bruno. Jamais fomos modernos. Rio de Janeiro, Editora 34, 1994.

L'ECOLE DE CHICAGO. Naissance de l'écologie urbaine. Paris, Aubier Montaigne, 1984.

LIMENA, Maria Margarida Cavalcanti. "Mundo em crise?" In REVISTA MARGEM. Temporalidades. Faculdade de Ciências Sociais - PUC - SP. Educ, 1996. p. 60-70.

MAC DOUGALL, David. "Films de Mémoire". In: PIAULT, Colette (Coordination). Journal des Anthropologues, Anthropologie Visuelle, número Special 47-48, Printemps 1992 p. 75-85.

MAFFESOLI, Michel. Une lecture de Georg Simmel. In: Revue des Sciences Humaines et Sociales. Société, n. 74. Paris, Dunod, 2001/4

MAFFESOLI, Michel. Aux creux des apparences. Pour une éthique de l'esthétique. Paris, Plon, 1990.

MAUSS, Marcel. Sociologia e Antropologia. São Paulo, EPU, EDUSP, 1974.

MORAES FILHO, Evaristo (Org). Simmel. São Paulo: Ática, 1983.

OLIVEN, Ruben. Urbanização e mudança social no Brasil. Petrópolis, Vozes, 1980.

OLIVEN, Ruben George. Violência e Cultura. Petrópolis, Vozes, 1985.

PETONNET, Colette. Espaces habités, ethnologie des banlieues. Paris, Galilée, $1982 .$.

RABINOW, Paul. Antropologia da razão. Rio de Janeiro, Dumará, 2002.

RICOEUR, Paul. La mémoire, l'histoire, l'oubli. Paris, Seuil, 2000.

RICOEUR, Paul. O si-mesmo como um outro, São Paulo. Papirus, 1991.

SCHUTZ, Alfred. Estudios sobre teoria social. Buenos Aires, Amorrortu editores, 1972.

SENNETT, Richard. O Declínio do Homem Público - As tiranias da intimidade, São Paulo, Companhia das Letras, 1988.

SIMMEL, Jorge. Cultura femenina y otros ensayos. Madrid, Revista de Occidente, 1934.

SIMMEL, Georg. "A metrópole e a vida mental". In: VELHO, Otávio G. (org). O fenômeno urbano. Rio de Janeiro, Zahar, 1979.

SIMMEL, Georg. Comment les formes sociales se maintiennent. In : Sociologie et Epistémologie. Paris, PUF. 1981.

SIMMEL, Georg. Le problème de la sociologie. In : Sociologie et Epistémologie. Paris, PUF. 1981. SIMMEL, Georg. Questões fundamentais da sociologia. RJ, Jorge Zahar, 2006.

SOARES, Luiz Eduardo. "Homicídios Dolosos Praticados contra Menores no Estado do Rio de Janeiro. Relatório de pesquisa desenvolvido como parte do plano de trabalho do Projeto Se Essa Rua Fosse Minha" (FASE, IBASE, IDAC, ISER). Rio de Janeiro, 1991.

SOARES, Luiz Eduardo. "Violência e cultura do medo no Rio de Janeiro". Mimiog. Palestra proferida no PPG Antropologia Social UFRGS, março 1995.

SOARES, Luiz Eduardo. O Rigor da Indisciplina. Rio de Janeiro, Relume-Dumara, 1994.

VELHO, Gilberto. A utopia urbana. RJ, Zahar, 1973. 
VELHO, Gilberto. Individualismo e cultura. Notas para uma antropologia da sociedade contemporânea. Rio de Janeiro, Zahar, 1981.

VELHO, Gilberto "O cotidiano da violência: identidade e sobrevivência". In: Boletim do Museu nacional. Nova série, Rio de Janeiro, Brasil. Antropologia n ${ }^{\circ} 56$ - 30 de abril de 1987.

VELHO, Gilberto. Projeto e metamorfose. Antropologia das sociedades complexas. RJ, Jorge Zahar, 1994.

VELHO, Otávio G. (org). O fenômeno urbano. Rio de Janeiro, Zahar, 1979.

WAGNER, Helmut R. (Org. e Introdução). Fenomenologia e relações sociais. Textos escolhidos de Alfred Schutz. RJ, Zahar, 1979.

WAIZBORT, Leopoldo. As aventuras de Georg Simmel. São Paulo, Editora 34, 2000.

WEBER, Max. La ville. Paris, Aubier Montaigne, 1982.

WWW.sjs.rs.gov.br. Consultas em 2001 e 2002.

ZALUAR, Alba. A máquina e a revolta. São Paulo, Brasiliense, 1985.

ZALUAR, Alba. Condomínio do diabo. Rio de Janeiro, Revan e UFRJ, 1994. 